\title{
Properties and Regulation of Valine-sensitive Acetolactate Synthase from Mitochondria of Euglena gracilis
}

\author{
By YUJI ODA, YOSHIHISA NAKANO AND \\ SHOZABURO KITAOKA* \\ Department of Agricultural Chemistry, University of Osaka Prefecture, Sakai, Osaka 591, \\ Japan
}

(Received 17 September 1981)

\begin{abstract}
Acetolactate synthase from mitochondria of Euglena gracilis was markedly activated by ATP and feedback-inhibited by valine and, to a lesser extent, by other branched-chain amino acids. 2-Oxobutyrate, a substrate converted to acetohydroxybutyrate, had a much higher affinity for this enzyme than pyruvate and markedly inhibited the formation of acetolactate from pyruvate. The inhibition of growth of $E$. gracilis by threonine and the relief of this inhibition by valine are explained by these characteristic properties of $E$. gracilis acetolactate synthase, the key enzyme in the biosynthesis of branched-chain amino acids.
\end{abstract}

\section{IN TRODUCTION}

Acetolactate synthase (EC 4.1.3.18), or acetohydroxy acid synthase, is one of the enzymes involved in the common biosynthetic pathway of isoleucine, valine and leucine (Umbarger, 1978). Since this enzyme, which catalyses the formation of precursors of these branched-chain amino acids, is under the control of the end-products, intensive studies have been made on the biochemical and genetical regulation of the enzyme from bacteria (Iaccarino et al., 1978; De Felice et al., 1979). Acetolactate synthase has been studied less intensively in eukaryotic organisms, probably because of the lability of the eukaryotic enzymes (Magee \& de Robichon-Szulmajster, 1968; Miflin, 1971; Glatzer et al., 1972; Takenaka \& Kuwana, 1972).

In previous papers we have reported that exogenous threonine inhibits the growth of Euglena gracilis (Oda et al., 1982b) and that the inhibition is due to a disturbance in the conversion of 2-oxo acids to 2-aceto-2-hydroxy acids catalysed by acetolactate synthase. This was related to isoleucine-valine biosynthesis in mitochondria (Oda et al., 1982a). The present paper reports the unique properties and regulation of valine-sensitive acetolactate synthase from mitochondria of $E$. gracilis.

\section{METHODS}

Organism and culture. Euglena gracilis SM-ZK (a streptomycin-bleached mutant derived from strain $\mathrm{z}$ ) was cultured in a cyanocobalamin-limited medium $\left(50 \mathrm{ng} \mathrm{l}^{-1}\right)$, as reported previously (Oda et al., $1982 a$ ).

Preparation of the mitochondrial fraction as enzyme. A cell homogenate prepared by the method of Tokunaga et al. (1976) was centrifuged at $10000 \mathrm{~g}$ for $10 \mathrm{~min}$. The pellet of physiologically intact mitochondria was washed and suspended in $10 \mathrm{~mm}-3-(N$-morpholino)propanesulphonic acid (MOPS)/KOH buffer (pH 7.5) containing $0.25 \mathrm{M}$-sucrose. This suspension $\left(5.0 \mathrm{mg}\right.$ protein $\left.\mathrm{ml}^{-1}\right)$ was used as the enzyme.

Enzyme assay. The activity of acetolactate synthase was assayed by the method of Takenaka \& Kuwana (1972). The reaction mixture, containing $50 \mathrm{~mm}$-sodium pyruvate, $1 \mathrm{~mm}$-thiamin pyrophosphate (TPP), $0.5 \mathrm{~mm}$-ATP, $100 \mathrm{~mm}$-potassium phosphate buffer $(\mathrm{pH} 7.5)$ and enzyme $(0.5 \mathrm{mg}$ protein) in a total volume of 1.0 $\mathrm{ml}$, was incubated at $25^{\circ} \mathrm{C}$ for $30 \mathrm{~min}$. The reaction was stopped by the addition of $0.1 \mathrm{ml}$ of $3 \mathrm{M}-\mathrm{H}_{2} \mathrm{SO}_{4}$ and the acetolactate synthesized was converted into acetoin (acetylmethylcarbinol) by maintaining the mixture at $40^{\circ} \mathrm{C}$ 
for $1 \mathrm{~h}$. After centrifuging, acetoin in the supernatant was determined by the method of Westerfeld (1945). The specific activity of enzyme was expressed as $\mu \mathrm{mol}$ acetolactate formed $\mathrm{h}^{-1}$ (mg protein) ${ }^{-1}$. Acetoin was not formed directly from pyruvate during the enzyme reaction since no acetoin was detected in the supernatant when the reaction was stopped by adding $0.1 \mathrm{ml}$ of $2.5 \mathrm{M}-\mathrm{NaOH}$ (Glatzer et al., 1972). Acetohydroxybutyrate was determined by the microbiological method of Leavitt \& Umbarger (1960). Protein was determined by the method of Bradford (1976).

Identification of reaction products. The acidic supernatant (obtained after the addition of $\mathrm{H}_{2} \mathrm{SO}_{4}$ to the enzyme reaction as described above) containing acetoin (acetylmethylcarbinol) formed from acetolactate, or acetoin and acetylethylcarbinol formed from acetohydroxybutyrate, was neutralized with $0.3 \mathrm{mmol} \mathrm{Ba}(\mathrm{OH})_{2}$ and the mixture was agitated vigorously. After centrifuging, the supernatant was passed through columns of Dowex 1-X8 $\left(\mathrm{HCOO}^{-}\right.$form) and then Dowex $50-\mathrm{X} 8\left(\mathrm{H}^{+}\right.$form); the columns were washed with distilled water. The carbinols in the effluent were converted into the corresponding pteridine derivatives and separated on a thin-layer of cellulose powder by the method of Wagner et al. (1959). Authentic acetolactate and acetohydroxybutyrate were prepared by the methods of Krampitz (1957) and Kiritani \& Wagner (1971), respectively.

\section{RESULTS}

\section{Stability of E. gracilis acetolactate synthase}

During attempts to solubilize E. gracilis acetolactate synthase, the enzyme activity was completely lost by treatment of the mitochondrial fraction at $4{ }^{\circ} \mathrm{C}$ with Triton X-100, Brij 35 , sodium deoxycholate or sodium dodecyl sulphate (all at $0.2 \%, \mathrm{w} / \mathrm{v}$ ), or $\mathrm{KI}$ or $\mathrm{KClO}_{4}(0.4 \mathrm{M})$ for $5 \mathrm{~min}$, or by sonication in $1 \mathrm{M}$-phosphate buffer $(\mathrm{pH} \mathrm{7.5)}$ for $20 \mathrm{~s}$. Emulgen 910 and Tween 20 also failed to solubilize the enzyme; after treatments at $4{ }^{\circ} \mathrm{C}$ for 5 min only 65 and $18 \%$ of the original activity remained.

The untreated mitochondrial fraction was therefore employed as the enzyme preparation throughout the following experiments. Acetolactate production was directly proportional to the enzyme concentration in the reaction mixture up to $1.5 \mathrm{mg}$ protein $\mathrm{ml}^{-1}$. Storing the enzyme preparation at $4{ }^{\circ} \mathrm{C}$ for $24 \mathrm{~h}$ caused a decrease in enzyme activity to $46 \%$ of the original activity.

\section{Co-factor requirements}

Table 1 summarizes the co-factor requirements of $E$. gracilis acetolactate synthase. The activity depended on ATP and, to a lesser extent, on ADP, but not on AMP and other nucleotides. When potassium phosphate buffer was replaced by MOPS/KOH buffer, the activity was reduced to $65 \%$, indicating that $P_{i}$ stimulates the activity.

Acetolactate synthase from most organisms requires TPP or FAD (Szentirmai et al., 1970; Grimminger \& Umbarger, 1979), but omission and addition of these co-factors did not affect the activity of the $E$. gracilis enzyme. The activity was slightly inhibited by $2 \mathrm{~mm}-\mathrm{Mg}^{2+}$, but not by $1 \mathrm{~mm}$-EDTA. Dithiothreitol $(5 \mathrm{~mm})$ and, to a lesser extent, 2-mercaptoethanol stimulated the activity about $1 \cdot 34$-fold, but these SH-reagents strongly interfered with the Westerfeld reaction (Glatzer et al., 1972).

Even when the mitochondrial fraction was dialysed against MOPS/KOH buffer for $24 \mathrm{~h}$, the co-factor requirements of the enzyme (as in Table 1) did not change, although $83 \%$ of the original enzyme activity was lost.

\section{Optimum $\mathrm{pH}$ and temperature}

The optimum $\mathrm{pH}$ of $E$. gracilis acetolactate synthase was 7.5 in $100 \mathrm{~mm}$-potassium phosphate buffer; in the presence of valine the activity was reduced and the optimum $\mathrm{pH}$ was shifted to higher values (Fig. 1).

The activity increased with temperature up to $50^{\circ} \mathrm{C}$, but the valine sensitivity of the enzyme was highest at about $25^{\circ} \mathrm{C}$. High temperature might cause a change in enzyme structure with consequent loss of the valine sensitivity. 
Table 1. Co-factor requirements of acetolactate synthase

Adenine nucleotide $(0.5 \mathrm{~mm}), \mathrm{MgSO}_{4}(1.0 \mathrm{~mm})$ or FAD $(2.0 \mu \mathrm{M})$ was added to the reaction mixture as indicated.

$\begin{array}{ccc}\overbrace{\text { Omission }}^{\text {Alteration(s) to reaction mixture }} & \begin{array}{c}\text { Specific activity } \\ \text { Addition }\end{array} & 1.82 \\ \text { ATP } & - & 0.225 \\ \text { ATP } & \text { ADP } & 1.25 \\ \text { ATP } & \text { AMP } & 0.243 \\ \text { TPP } & - & 1.81 \\ \text { - } & \mathrm{Mg}^{2+} & 1.65 \\ \mathrm{P}_{\mathrm{i}}^{*} & \mathrm{FAD} & 1.77\end{array}$

* Phosphate buffer was replaced by MOPS/KOH buffer.

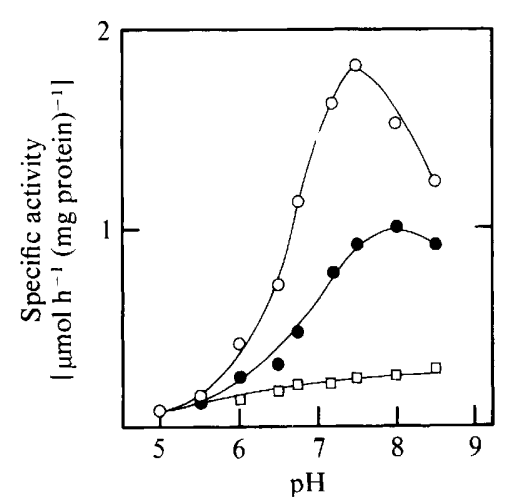

Fig. 1

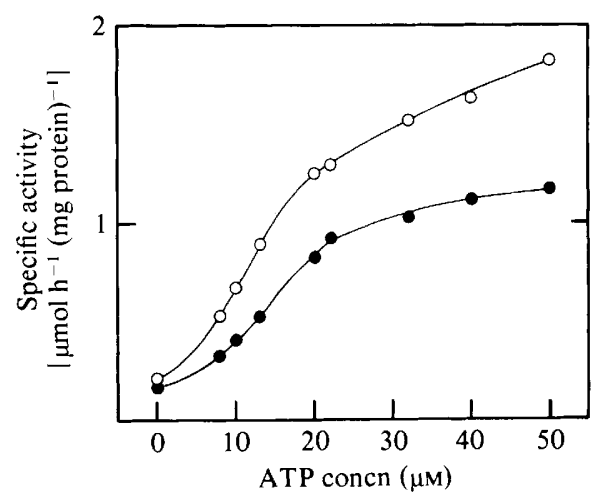

Fig. 2

Fig. 1. Effect of $\mathrm{pH}$ on acetolactate synthase and its inhibition by valine. Enzyme activity was determined without $\mathrm{L}$-valine $(\mathrm{O})$ and with $0.4 \mathrm{~mm}(O)$ and $5.0 \mathrm{~mm}(\square) \mathrm{L}$-valine.

Fig. 2. ATP saturation curves for acetolactate synthase. Enzyme activity was determined without L-valine $(O)$ and with $0.2 \mathrm{mM}-\mathrm{L}$-valine $(O)$.

Table 2. Effect of $\mathrm{L}-$ valine and other related amino acids on acetolactate synthase

Each amino acid was added to the reaction mixture at $5.0 \mathrm{~mm}$.

\begin{tabular}{lc}
\multicolumn{1}{c}{ Addition to } & Inhibition \\
reaction mixture & $(\%)$ \\
None & 0 \\
L-Valine & 89 \\
D-Valine & $1 \cdot 1$ \\
L-Leucine & 23 \\
L-Isoleucine & 32 \\
L-2-Aminobutyrate & 21 \\
L-Threonine & 6.6
\end{tabular}

\section{Inhibition by valine}

L-Valine inhibited the activity of $E$. gracilis acetolactate synthase (Table 2), and the percentage inhibition as a function of valine concentration showed a hyperbolic curve, unlike the enzymes in Neurospora crassa (Takenaka \& Kuwana, 1972) and Pseudomonas 


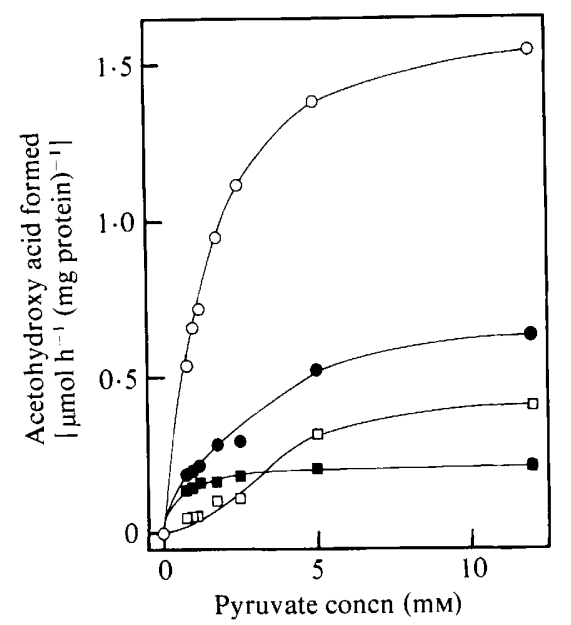

Fig. 3. Formation of acetohydroxy acids from pyruvate in the presence and absence of 2-oxobutyrate by acetolactate synthase: acetolactate $(O)$ formed in the absence of 2-oxobutyrate; acetolactate ( $\square$ ), acetohydroxybutyrate $(\square)$ and total acetohydroxy acids $(O)$ formed in the presence of $2.0 \mathrm{~mm}$ 2-oxobutyrate.

aeruginosa (Arfin \& Koziell, 1973). This inhibition was specific for the L-isomer. Isoleucine, leucine and 2-aminobutyrate were not effective inhibitors. At a concentration of $0.2 \mathrm{~mm}$, valine, isoleucine and leucine inhibited the enzyme by 29,9 and $21 \%$, respectively, while inhibition by combinations of these amino acids $(0.2 \mathrm{~mm}$ for each L-amino acid), valine + isoleucine, valine + leucine, isoleucine + leucine and valine + isoleucine + leucine, was 27 , 48,27 and $51 \%$ respectively.

The enzyme followed normal Michaelis-Menten kinetics toward pyruvate, giving a $K_{\mathrm{m}}$ of $2.1 \mathrm{mM}$. Valine inhibited the enzyme non-competitively; the $K_{\mathrm{i}}$ was $0.28 \mathrm{~mm}$.

Increasing the concentration of ATP activated the enzyme in the presence or absence of valine (Fig. 2). The ATP concentration which gave the half-maximal activation was $20 \mu \mathrm{M}$. These kinetics indicate that this enzyme is regulated allosterically by ATP, and that valine has no effect on the allostericity.

\section{Effect of 2-oxobutyrate}

The carbinols produced from acetohydroxy acids by $E$. gracilis acetolactate synthase were identified as described in Methods. Only acetoin (acetylmethylcarbinol) was detected in the reaction mixture containing $50 \mathrm{~mm}$-pyruvate alone; acetylethylcarbinol, in addition to acetoin, was detected when $10 \mathrm{~mm}$-2-oxobutyrate was added to the reaction mixture containing 50 mM-pyruvate.

Figure 3 shows formation by acetolactate synthase of acetolactate and acetohydroxybutyrate from different concentrations of pyruvate and $2.0 \mathrm{~mm}$-2-oxobutyrate. 2-Oxobutyrate not only reduced the total amount of acetohydroxy acids produced but also caused a preferential production of acetohydroxybutyrate when less than $3.2 \mathrm{~mm}$-pyruvate was present. From the Lineweaver-Burk plots in the presence and absence of $0.4 \mathrm{~mm}$ 2-oxobutyrate the inhibition by 2-oxobutyrate was shown to be competitive toward pyruvate, giving a $K_{\mathrm{i}}$ of $0.13 \mathrm{~mm}$.

\section{DISCUSSION}

Purification of acetolactate synthase has been difficult because of its lability (Umbarger, 1978) except with the enzyme from Pseudomonas aeruginosa (Arfin \& Koziell, 1973). Recently, Grimminger \& Umbarger (1979) have succeeded in purifying the enzyme from 
Escherichia coli K12 using glycerol and a buffer of high ionic strength. In eukaryotic cells purification of the enzyme is complicated by the requirement to extract it from mitochondria where it is located (Umbarger, 1978). Acetolactate synthase in permeabilized cells of Saccharomyces cerevisiae is effectively inhibited by valine, but some physical and chemical treatments of the enzyme reduced its valine sensitivity (Magee \& de Robichon-Szulmajster, 1968). A valine-sensitive acetolactate synthase was also extracted from $N$. crassa mitochondria by sonication in $1 \mathrm{M}$-potassium phosphate buffer (Kuwana \& Date, 1975); this enzyme appears to be stabilized by $\mathrm{P}_{\mathrm{i}}$. However, the E. gracilis enzyme was not solubilized under the similar conditions. It seems that the activity and valine sensitivity of the $E$. gracilis enzyme are immediately lost when the enzyme is extracted from the mitochondrial membrane.

Acetolactate synthase from E. gracilis mitochondria required ATP as a co-factor. Takenaka \& Kuwana (1972) reported that inhibition of the $N$. crassa enzyme by valine was relieved by ATP or ADP and that the enzyme was activated by ATP, ADP or $\mathrm{P}_{\mathrm{i}}$, but the $E$. gracilis enzyme was activated allosterically by ATP, keeping the valine sensitivity unchanged.

Other co-factors reported to be necessary for acetolactate synthase from other organisms (Szentirmai et al., 1970; Glatzer et al., 1972; Grimminger \& Umbarger, 1979) were either slightly inhibitory or were ineffective with the $E$. gracilis enzyme; the co-factor requirements of the E. gracilis enzyme are similar to those reported for the $S$. cerevisiae enzyme (Magee \& de Robichon-Szulmajster, 1968). TPP is essential in some bacteria (Szentirmai et al., 1970) as the carrier of a hydroxyethyl group to form acetohydroxy acids, and ineffectiveness of exogenous TPP in E. gracilis may indicate that TPP is tightly bound to the E. gracilis enzyme protein.

Escherichia coli (Grimminger \& Umbarger, 1979), Salmonella typhimurium (O'Neill \& Freundlich, 1972) and Aerobacter aerogenes (Asada et al., 1976) are known to contain multiple acetolactate synthases, whose activities are under the control of inhibition and repression by the end-products, valine, isoleucine and leucine. In eukaryotic organisms such as $N$. crassa (Takena \& Kuwana, 1972) and ripening peas (Davies, 1964), two types of acetolactate-forming enzyme have been found, one insensitive to valine with an optimum $\mathrm{pH}$ 6.0 and the other sensitive to valine with an optimum $\mathrm{pH} 7.4$ to 8.5 . The $E$. gracilis acetolactate synthase showed the highest activity at $\mathrm{pH} 7.5$ and had no apparent separate activity. The activity of the $E$. gracilis enzyme was lowered by valine with a shift of the optimum $\mathrm{pH}$, indicating that it is analogous to the valine-sensitive enzyme in Thiobacillus acidophilus (Proteau \& Silver, 1978). Harding et al. (1970) showed that the valine-insensitive activity at $\mathrm{pH} 6.0$ in $N$. crassa mitochondria was included in the pyruvate dehydrogenase complex.

Formation of acetolactate from pyruvate by acetolactate synthase was inhibited in the presence of 2-oxobutyrate, whereas production of acetohydroxybutyrate was stimulated. Acetolactate synthase in some micro-organisms (Szentirmai \& Horváth, 1976) has two binding sites for the two substrates - in the synthesis of acetolactate both sites bind pyruvate, while in the synthesis of acetohydroxybutyrate one of the two sites binds pyruvate to form a hydroxyethyl group and the other binds 2 -oxobutyrate (Szentirmai \& Horváth, 1976). Since pyruvate and 2-oxobutyrate compete for the binding sites and the E. gracilis enzyme has a much higher affinity for 2-oxobutyrate than pyruvate, acetohydroxybutyrate is the major product at low concentrations of pyruvate and the total production of acetohydroxy acids was reduced in the presence of 2-oxobutyrate (Fig. 3). Szentirmai et al. (1970) suggested that the difference in affinities of acetolactate synthase for pyruvate and 2-oxobutyrate is an important regulatory adaptation for the balanced synthesis of isoleucine and valine, since cells would be expected to have higher concentration of pyruvate than 2-oxobutyrate under normal conditions. Previously we reported that growth inhibition of $E$. gracilis by threonine was due to lowered production of valine, since threonine is converted to 2-oxobutyrate in the cytosol and this 2-oxo acid both stimulates isoleucine synthesis and inhibits valine synthesis in 
mitochondria (Oda et al., 1982a). This conclusion is supported by the present results; acetolactate synthase from E. gracilis mitochondria has a much higher affinity for 2-oxobutyrate than for pyruvate, and in the presence of the two 2-oxo acids production of acetohydroxybutyrate, an intermediate of the isoleucine synthesis, is preferred to that of acetolactate. Acetolactate synthase thus plays a central role in the growth inhibition by threonine in E. gracilis.

We thank Dr H. Kuwana, Kwansei Gakuin University, for his helpful advice.

\section{REFERENCES}

Arfin, S. M. \& Koziell, D. A. (1973). Acetolactate synthase of Pseudomonas aeruginosa. I. Purification and allosteric properties. Biochimica et biophysica acta 321, 348-355.

Asada, Y., OkuZawa, Y. \& Yamaguchi, K. (1976). The existence of three types of acetohydroxy acid synthetase in an isoleucine-requiring mutant of Aerobacter aerogenes. Biochimica et biophysica acta 429, 1029-1035.

BRADFORD, M. M. (1976). A rapid and sensitive method for the quantitation of microgram quantities of protein utilizing the principle of protein-dye binding. Analytical Biochemistry 72, 248-254.

DAviEs, M. E. (1964). Acetolactate and acetoin synthesis in ripening peas. Plant Physiology 39, 53-59.

De Felice, M., Levinthal, M., Iaccarino, M. \& GuARdiola, J. (1979). Growth inhibition as a consequence of antagonism between related amino acids: effect of valine in Escherichia coli K-12. Microbiological Reviews 43, 42-58.

Glatzer, L., EAKIN, E. \& WAGNer, R. P. (1972). Acetohydroxy acid synthetase with a $\mathrm{pH}$ optimum of 7.5 from Neurospora crassa mitochondria: characterization and partial purification. Journal of Bacteriology 112, 453-464.

Grimminger, H. \& UMBarger, H. E. (1979). Acetohydroxy acid synthase I of Escherichia coli: purification and properties. Journal of Bacteriology 137, 846-853.

Harding, R. W., Caroline, D. F. \& Wagner, R. P. (1970). The pyruvate dehydrogenase complex from the mitochondrial fraction of Neurospora crassa. Archives of Biochemistry and Biophysics 138 , 653-661.

Iaccarino, M., Guardiola, J., De Felice, M. \& FABRE, R. (1978). Regulation of isoleucine and valine biosynthesis. Current Topics in Cellular Regulation 14, 29-73.

Kiritani, K. \& WAGNER, R. P. (1971). a-Hydroxy$\beta$-keto acid reductoisomerase (Neurospora crassa). Methods in Enzymology 17A, 745-750.

Krampitz, L. O. (1957). Preparation and determination of acetoin, diacetyl, and acetolactate. Methods in Enzymology 3, 277-283.

Kuwana, H. \& Date, M. (1975). Solubilization of valine-sensitive acetohydroxy acid synthetase from Neurospora mitochondria. Journal of Biochemistry 77, 257-259.

LeAvitT, R. \& UMBarger, H. E. (1960). Colorimetric method for the estimation of growth in cup assays. Journal of Bacteriology 80, 18-20.

MAgeE, P. T. \& DE RoBIChon-SzulmajSTER, H.
(1968). The regulation of isoleucine-valine biosynthesis in Saccharomyces cerevisiae. 3. Properties and regulation of the activity of acetohydroxy acid synthetase. European Journal of Biochemistry $\mathbf{3}$, 507-511.

Miflin, B. J. (1971). Co-operative feedback control of barley acetohydroxy acid synthetase by leucine, isoleucine and valine. Archives of Biochemistry and Biophysics 146, 542-550.

Oda, Y., NAKano, Y. \& KitAoKA, S. $(1982 a)$. The mechanism of growth inhibition by threonine in Euglena gracilis. Regulation of isoleucine-valine biosynthesis by 2-oxobutyrate. Archives of Microbiology (in the Press).

ODA, Y., NAKANO, Y. \& KitAoKA, S. (1982b). Utilization and toxicity of exogenous amino acids in Euglena gracilis. Journal of General Microbiology 128, 853-858.

O'Neill, J. P. \& Freundlich, M. (1972). Two forms of biosynthetic acetohydroxy acid synthetase in Salmonella typhimurium. Biochemical and Biophysical Research Communications 48, 437-443.

Proteau, G. \& Silver, M. (1978). Effects of amino acids on Thiobacillus acidophilus. I. Growth studies with special reference to valine. Canadian Journal of Microbiology 24, 1158-1163.

Szentirmai, A. \& Horváth, I. (1976). Regulation of branched-chain amino acid biosynthesis. Acta microbiologica Academiae scientiarum hungaricae 23, 137-149.

Szentirmai, A., Horváth, I. \& ZsadÁnyi, J. (1970). Properties of acetohydroxy acid synthetase in Streptomyces rimosus. Acta microbiologica Academiae scientiarum hungaricae 17, 105-115.

TAKEnaKa, S. \& Kuwana, H. (1972). Control of acetohydroxy acid synthetase in Neurospora crassa. Journal of Biochemistry 72, 1139-1145.

Tokunaga, M., Nakano, Y. \& KitaOKA, S. (1976). Preparation of physiologically intact mitochondria from Euglena gracilis z. Agricultural and Biological Chemistry 40, 1439-1440.

UMBARGER, H. E. (1978). Amino acid biosynthesis and its regulation. Annual Review of Biochemistry 47, 533-606.

WAGNer, R. P., Berquist, A. \& Forrest, H. S. (1959). The accumulation of acetylmethylcarbinol and acetylethylcarbinol by a mutant of Neurospora crassa and its significance in the biosynthesis of isoleucine and valine. Journal of Biological Chemistry 234, 99-104.

WESTERFELD, W. W. (1945). A colorimetric determination of blood acetoin. Journal of Biological Chemistry 161, 495-502. 